\title{
THE REQUIREMENT OF A TRYPSIN-LIKE ACROSOMAL ENZYME FOR FERTILIZATION IN THE DOMESTIC FOWL
}

\author{
M. B. PALMER* AND B. HOWARTH, JR \\ Department of Poultry Science, University of Georgia, \\ Athens, Georgia 30601, U.S.A.
}

(Received 24th August 1972)

\begin{abstract}
Summary. The effect of a synthetic, irreversible trypsin inhibitor (TLCK: tosyl-L-lysine chloromethyl ketone) upon the fertilizing capacity of spermatozoa from four individual cocks was evaluated. Recently ejaculated spermatozoa were incubated with TLCK for 20 $\min$ at $37^{\circ} \mathrm{C}$ before insemination. The inhibitor was used at two concentrations that did not affect sperm motility. The mean fertility for the unincubated control, non-TLCK-incubated control and $50 \mu \mathrm{g}$ TLCK-incubated semen groups was $91.8,85.4$ and $51.9 \%$, respectively. Using $75 \mu \mathrm{g}$ TLCK, the mean fertility for the unincubated control, incubated control and treated semen groups was $93 \cdot 1,74 \cdot 1$ and $24 \cdot 4 \%$, respectively. These results demonstrate the effectiveness of a synthetic trypsin inhibitor in successfully reducing fertilization in vivo and thus suggest the need for an active acrosomal trypsin-like enzyme for fertilization of the hen's ovum.
\end{abstract}

\section{INTRODUCTION}

The presence of an acrosomal trypsin-like enzyme or protease has been demonstrated in spermatozoa of several mammalian species (Gaddum \& Blandau, 1970), including the dog (Yamane, 1935a, b), rabbit (Stambaugh \& Buckley, 1969; Zaneveld, Srivastava \& Williams, 1969), ram (Srivastava, Adams \& Hartree, 1965), bull (Multamaki \& Niemi, 1969), monkey and man (Stambaugh \& Buckley, 1970; Zaneveld, Polakoski, Foley \& Williams, 1971). Cock spermatozoa have also been shown to contain a high trypsin-like enzymatic activity (Buruiana, 1956; Ho \& Meizel, 1970). More recently, Polakoski (1972) has shown that the high trypsin-like enzymatic activity is present in the acrosomes (acrosomal extracts) of cock spermatozoa.

Stambaugh \& Buckley (1969) demonstrated the significance of the trypsinlike enzyme (TLE) in rabbit epididymal spermatozoa by showing its activity (in vitro) in the dissolution of the zona pellucida. The same authors also demonstrated that TLE activity of epididymal spermatozoa could be completely inhibited by soybean or lima-bean trypsin inhibitors. Zaneveld et al. (1969)

* Present address: Abraham Baldwin Agricultural College, Tifton, Georgia 31794, U.S.A. 
observed that TLE activity was absent in ejaculated rabbit spermatozoa but present in capacitated spermatozoa. They related this observation to the addition and removal of a seminal plasma trypsin inhibitor. Trypsin inhibitors have been found in the seminal fluid of many mammalian species as well as the fowl (Feeney \& Allison, 1969). Recent studies (Zaneveld \& Polakoski, 1971; Polakoski, 1971), have provided evidence for the occurrence of a TLE-TLE inhibitor complex in ejaculated spermatozoa from a number of mammalian species but the absence of such a complex in cock spermatozoa. The absence of a TLE-TLE inhibitor complex in cock spermatozoa would support the observation that avian spermatozoa do not require capacitation in order to fertilize ova (Howarth, 1970).

The essential rôle of a TLE in the fertilization of rabbit ova in vivo has been demonstrated through the use of trypsin inhibitors. Fertilization in vivo was inhibited by preincubation of capacitated rabbit spermatozoa with pancreatic trypsin inhibitor or rabbit seminal plasma trypsin inhibitor (Zaneveld, Robertson, Kessler \& Williams, 1971). Treatment of ejaculated and capacitated rabbit spermatozoa with synthetic irreversible trypsin inhibitors, such as tosyl lysine chloromethyl ketone (TLCK), also prevented fertilization (Zaneveld, Robertson \& Williams, 1970). In the present study, the necessity for an active trypsin-like acrosomal enzyme for fertilization of the hen's ovum was evaluated by treating cock spermatozoa with TLCK before insemination and observing its effect on fertility.

\section{MATERIALS AND METHODS}

Spermatozoa from each of four Athens Randombred cocks were treated with TLCK at each of two concentrations (50 and $75 \mu \mathrm{g} / 90 \times 10^{4}$ spermatozca). Single ejaculates from the individual cocks were diluted 1:4 with modified Ringer's solution and were then split into three equal portions. One aliquot of spermatozoa (treated semen group) was mixed with the appropriate amount of TLCK dissolved in $1 \mathrm{ml}$ modified Ringer's solution (50 or $75 \mu \mathrm{g}$ TLCK/ $90 \times 10^{6}$ spermatozoa). The spermatozoa-TLCK suspension was then incubated at $37^{\circ} \mathrm{C}$ for $20 \mathrm{~min}$. A second aliquot (incubated control semen group) was incubated under the same conditions as the treated semen but without the addition of TLCK. The purpose of this semen group was to test for an incubation effect upon sperm fertility. The third aliquot (unincubated control semen group) was immediately used for insemination.

Before insemination, the motility of spermatozoa in each of the three aliquots mentioned above was evaluated. A subjective visual assessment of motility was made by a single trained individual and expressed as a percentage in units of 10 .

Each of the three aliquots of spermatozoa was used to inseminate ten laying White Leghorn hens. Each hen was inseminated weekly with $90 \times 10^{6}$ spermatozoa. Eggs were set at weekly intervals for 2 weeks at each level of TLCK treatment. Collection of eggs for fertility evaluation was initiated on the 2nd day following insemination; thus, eggs were collected for two 5-day periods. Fertility was determined by candling eggs on the 4th day of incubation. Eggs 
that appeared 'infertile' were broken open and examined macroscopically for evidence of embryonic development.

Data were analysed statistically by the analysis of variance (Snedecor \& Cochran, 1967) and the means were compared by the LSD test of Fisher (Ostle, 1963).

\section{RESULTS}

In preliminary investigations, treatment with $100 \mu \mathrm{g}$ TLCK $/ 90 \times 10^{6}$ spermatozoa was toxic to cock spermatozoa as assessed by a complete loss of motility at the end of the incubation period. In the present study, sperm motility ranged from 60 to $90 \%$. All three aliquots of spermatozoa from a single ejaculate, i.e. the unincubated control, incubated control and treated aliquots, consistently maintained comparable motility during the experimental period before insemination. Furthermore, there was no indication that sperm motility following incubation with $50 \mu \mathrm{g}$ TLCK differed from sperm motility following incubation with $75 \mu \mathrm{g}$ TLGK. Thus, treatment of cock spermatozoa with TLCK at the two concentrations used in this study had no visible effect on motility.

Since the fertility of TLCK-treated semen from each of the four cocks did not differ significantly, the fertility results for their semen were pooled for each of the two concentrations of TLCK evaluated. Incubation of cock spermatozoa with TLCK before insemination significantly $(P<0.01)$ reduced fertility (Table 1). This was apparent for both concentrations of TLCK used in this

Table 1. The effect of an irreversible trypsin inhibitor, TLCK, on the fertilizing ability of cock spermatozoa

\begin{tabular}{c|l|c|c|c}
\hline \multirow{2}{*}{$\begin{array}{c}\text { Semen } \\
\text { group }\end{array}$} & \multicolumn{1}{|c|}{ Treatment } & No. of eggs set & No. of eggs fertile & \% fertile* \\
\hline \multirow{2}{*}{ A } & Unincubated control & 340 & 312 & $91 \cdot 8^{\mathrm{a}}$ \\
& Incubated control & 294 & 251 & $85 \cdot 4^{\mathrm{a}}$ \\
& Treated & $322 \dagger$ & 167 & $51 \cdot 9^{\mathrm{b}}$ \\
B & Unincubated control & 349 & 325 & $93 \cdot 1^{\mathrm{a}}$ \\
& Incubated control & 320 & 237 & $74 \cdot 1^{\mathrm{a}}$ \\
& Treated & $316 \dagger$ & 77 & $24 \cdot 4^{\mathrm{b}}$ \\
\hline
\end{tabular}

$\mathrm{A}=50 \mu \mathrm{g}$ TLCK $/ 90 \times 10^{6}$ spermatozoa. $\mathrm{B}=75 \mu \mathrm{g}$ TLCK $/ 90 \times 10^{6}$ spermatozoa.

* Fertility percentages with different superscripts are significantly different $(P<0.01)$.

$\dagger$ Represents the number of eggs laid by forty hens over a period of 10 days (ten hens per cock).

study. Differences in fertility for the incubated control and unincubated control semen were not significant. While incubation of spermatozoa under the conditions of this study reduced fertility, incubation was not responsible for the drastic decline in fertility resulting from the use of TLGK-treated semen. The fertility of TLCK-treated semen was significantly lower than the fertility of either the incubated or unincubated control semen. This observation was consistent for semen from each of the four cocks exposed to each of the two concentrations of TLCK. 


\section{DISCUSSION}

By contrast with the series of investments which surround the mammalian ovum, the avian ovum is only enclosed by a vitelline membrane at the time of ovulation and fertilization. The composition of the vitelline membrane of the hen's ovum at the time of ovulation has been described by Bellairs, Harkness \& Harkness (1963) as a single layer of connective tissue-like protein. In the process of fertilization, therefore, cock spermatozoa have only to penetrate the vitelline membrane of the hen's ovum. The demonstration in this study that TLCK effectively reduced fertilization in vivo suggests the need for an active acrosomal TLE in the fertilization process. The TLE in cock spermatozoa probably enables spermatozoa to penetrate the vitelline membrane of the hen's ovum. Recent observations in this laboratory support this hypothesis. The vitelline membranes of recently ovulated hen ova in vitro were observed to rupture in the region of the germinal disc within $35 \mathrm{~min}$ after the addition of $0.05 \mathrm{ml}$ of recently ejaculated cock semen. By contrast, the vitelline membranes of ova exposed to TLCK-treated spermatozoa failed to rupture. These observations demonstrate the necessity for an active acrosomal TLE for digestion and penetration of the vitelline membrane of the hen's ovum.

\section{REFERENCES}

Bellairs, R., Harkness, M. \& Harkness, R. D. (1963) The vitelline membrane of the hen's egg: a chemical and electron microscopical study. F. Ultrastruct. Res. 8, 339.

Burutana, L. M. (1956) Sur l'activité hyaluronidasique et trypsinique du sperme. Naturwissenschaften, $43,523$.

Freney, R. E. \& Allison, R. G. (1969) Evolutionary biochemistry of proteins, p. 213. Wiley, New York.

Gaddum, P. \& Blandau, R. J. (1970) Proteolytic reaction of mammalian spermatozoa on gelatin membranes. Science, $\mathcal{N} . Y .170,749$.

Ho, J. J. L. \& MEIzEL, S. (1970) Electrophoretic detection of multiple forms of trypsin-like activity in spermatozoa of the domestic fowl. F. Reprod. Fert. 23, 177.

Howarth, B., JR (1970) An examination for sperm capacitation in the fowl. Biol. Reprod. 3, 338.

MULTAMAKI, S. \& NiEMI, M. (1969) Zona pellucida dissolving protease in an acrosomal preparation of the bull spermatozoa. Scand. 7. clin. Lab. Invest. 23, 108.

Ostle, B. (1963) Statistics in research, 2nd edn. The Iowa State University Press, Ames, Iowa.

Polakoski, K. L. (1971) Enzymes and enzyme inhibitors involved in animal fertilization. M.S. thesis, Department of Biochemistry, University of Georgia.

Polakoski, K. L. (1972) Properties and function of enzymes and inhibitors involved in mammalian fertilization. Ph.D. thesis, Department of Biochemistry, University of Georgia.

SNedecor, G. M. \& Cochran, W. G. (1967) Statistical methods, 6th edn. The Iowa State University Press, Ames, Iowa.

Srivastava, P. N., Adams, G. E. \& Hartree, E. F. (1965) Enzymatic action of acrosomal preparations on the rabbit ovum in vitro. F. Reprod. Fert. 10,61.

Stambaugh, R. \& BuckLey, J. (1969) Identification and subcellular localization of the enzymes effecting penetration of the zona pellucida by rabbit spermatozoa. J. Reprod. Fert. 19, 423.

Stambaugh, R. \& Buckiey, J. (1970) Comparative studies of the acrosomal enzymes of rabbit, rhesus monkey, and human spermatozoa. Biol. Reprod. 3, 275.

YAmane, J. (1935a) Kausal-analytische Studien über die Befruchtung des Kanincheneies. I. Die Dispersion der Follikelzellen und die Ablösung der Zellen der Corona radiata des Eies durch Spermatozoen. Cytologia, 6, 233.

Yamane, J. (1935b) Kausal-analytische Studien über die Befruchtung des Kanincheneies. II. Die Isolierung der auf das Eizytoplasma aufösend wirkenden Substanzen aus den Spermatozoen. Cytologia, 6, 475.

Zaneveld, L. J. D. \& Polakoski, K. L. (1971) Characterization of sperm acrosomal hyaluronidase and acrosin. Biol. Reprod. 5, 85 (Abstr.).

Zaneveld, L. J. D., Polakoski, K. L., Foley, C. W. \& Williams, W. L. (1971) The role of acrosin, 
an acrosomal protease, and acrosin inhibitor in capacitation of sperm. Fedn Proc. Fedn Am. Socs exp. Biol. 30, 595 (Abstr.).

Zaneveld, L. J. D., Robertson, R. T., Kessler, M. \& Williams, W. L. (1971) Inhibition of fertilization in vivo by pancreatic and seminal plasma trypsin inhibitors. F. Reprod. Fert. 25, 387.

Zaneveld, L. J. D., Robertson, R. T. \& Williams, W. L. (1970) Synthetic enzyme inhibitors as antifertility agents. FEBS Lett. 11, 345.

Zaneveld, L. J. D., Srivastava, P. N. \& Williams, W. L. (1969) Relationship of a trypsin-like enzyme in rabbit spermatozoa to capacitation. F. Reprod. Fert. 20, 337. 